\title{
E-destination: the future of e-mobility in the Lake Constance region, Germany
}

Tatjana Thimm

Tatjana Thimm is based at the Department of Business, Cultural and Legal Studies, HTWG Konstanz, Konstanz, Germany.
Received 30 October 2019 Revised 4 February 2020 5 June 2020

Accepted 9 September 2020

(C) Tatjana Thimm. Published in Journal of Tourism Futures. Published by Emerald Publishing Limited. This article is published under the Creative Commons Attribution (CC BY 4.0) license. Anyone may reproduce, distribute, translate and create derivative works of this article (for both commercial and non-commercial purposes), subject to full attribution to the original publication and authors. The full terms of this license may be seen at http:// creativecommons.org/ licences/by/4.0/legalcode

The author would like to thank three reviewers for their helpful comments.

Internationale BodenseeHochschule.

\begin{abstract}
Purpose - This paper aims to focus on the development of a vision for the Lake Constance region, Germany, as an e-destination, i.e. a destination where tourism mobility would be predominantly electric in the future.

Design/methodology/approach - This paper uses a scenario analysis based on factor analysis in addition to empirical data collected in 2016 and 2017 based on surveys and interviews with tourists and stakeholders.

Findings - The scenarios contain the optimistic, pessimistic and realistic models, including one scenario called e-destination, i.e. a projection of the future where tourism mobility consists predominantly of electro-mobility (e-mobility). This specific scenario is supported by the results of the empirical data.

Research limitations/implications - As the study focusses on e-mobility only, it leaves out other forms of mobility e.g. pedestrian or cycling mobility that also contribute to $\mathrm{CO}_{2}$ reduction. The sampling methods are not strictly randomised, but the tendencies they show are clear and supporting each other.

Practical implications - According to the tourists and stakeholders interviewed, it is quite likely that the region will become an e-destination in the future, but only with government support.

Social implications - The attitude-behaviour-gap was discussed as a possible explanation of tourists' behaviour in the study.

Originality/value - Studies on e-mobility in tourism are rare. (As far as the author knows) this paper presents the first analysis of the future of e-mobility in tourism using a German lake as a destination. Thus, it adds to the existing body of knowledge different possible projections of the future regarding e-mobility in a tourism destination.
\end{abstract}

Keywords Scenario analysis, Sustainable tourism, e-mobility, Lake Constance region, Mobility turn, Tourism mobility

Paper type Research paper

\section{Introduction}

This paper aims to show whether and in what form electro-mobility (e-mobility) can play a bigger role in the future focussing specifically on tourism in the rural region surrounding Lake Constance, Germany. E-mobility comprises all vehicles and connected infrastructure using electric propulsion including full electric vehicle and plug-in hybrids (Gartner, 2020). Although fuel cell technology is mostly linked to an e-engine, it is in this paper considered as alternative sustainable propulsion. Thus, this study focusses specifically on e-mobility which means in the Lake Constance region especially e-cars but also e-trains, e-bikes and e-busses. Tourists' trips to and from their vacation destinations and, to a lesser extent, their mobility within that destination results in the most $\mathrm{CO}_{2}$ emissions of all tourism-related activities but also offer the greatest potential for reducing emissions (Scott et al., 2010). Thus, cutting $\mathrm{CO}_{2}$ emissions in tourism mobility is by far the key factor in creating a more sustainable form of tourism (Thiel et al., 2016). E-mobility tends to be seen as a form of sustainable mobility, however, the environmental impact of electric vehicles is strongly related to the electricity mix (renewable energies versus coal, for example), the metals, such 
as lithium and cobalt, used to produce batteries, and the energy required to produce the batteries (Döring and Aiken, 2011).

Increasing the share of e-mobility in the Lake Constance region, especially in the remote rural areas, is particularly challenging due to technical, financial and administrative constraints, as well as a discrepancy between many tourists' sustainable attitudes and their actual behaviour (Cohen et al., 2014). The problem of this so-called attitude-behaviour gap has not yet been sufficiently explored (Barr and Prillwitz, 2014). Accordingly, the topics of transportation (new mobility offers) and mobility behaviour (decision-making for e-mobility) are given special attention (Kagerbauer et al., 2015). In this paper, the actual tourism mobility in the Lake Constance region (current situation) is compared with ideal tourism mobility (vision) and possible future tourism mobility (assumption). Based on these findings, this paper presents a vision in the form of a transitional scenario regarding a future emobility around Lake Constance, an e-destination, that is a destination where tourism mobility is based on e-mobility. The discourse about climate change has long stimulated a debate about the organisation of ecologically and economically viable mobility concepts. The concepts of zero carbon destination, multi-modal traffic and e-mobility overlap in this regard: the idea of zero carbon or carbon neutral destinations are supported by United Nations World Tourism Organisation (UNWTO) via the Davos Declaration and comprises the levels of government, international organisations, tourism industry, destinations, consumers, research and communication (World Tourism Organisation (UNWTO), 2008; Gössling, 2009). E-mobility as a sustainable kind of transportation in tourism forms, thus one component of a zero carbon destination. So does a sustainable modal shift, i.e. a change of means of transportation towards more sustainable options within multimodal trip options (Guiver et al., 2007; Zografos et al., 2009).

In scientific and political future scenarios, the large-scale expansion of sustainable mobility based on electric or fuel cell-powered engines has long been considered inevitable. With the German Federal Government's publication of the National Development Plan for ElectroMobility and the designation of eight model electro-mobility regions, the importance of this technology has also increased in public perception. The plan aims to establish Germany as the market leader for e-mobility and to have one million electric and hybrid vehicles on German roads by 2020 (Bundesregierung, 2011). However, the number of e-cars in Europe and specifically Germany is still very low and will not change considerably without massive governmental support (Auvinen et al., 2016). The motivation of the study is thus to link the aspects of e-mobility and destination development to assess possible future scenarios.

\section{Literature review}

\subsection{E-mobility in tourism}

The literature on sustainable mobility in tourism, which includes e-mobility in tourism, is extensive and continues to grow. It can be divided into several streams. One focusses on sustainability and the influence of distinct transport options on the energy system and climate change (Scott et al., 2010; Thiel et al., 2016). Another one deals with the mobility behaviour of travellers and their attitudes towards e-mobility (Götz et al., 2003; Becken, 2004; Friedl et al., 2005; Zschiegner and Yan, 2006; Böhler et al., 2006; Dickinson et al., 2011; Lumsdon and McGrath, 2011; Cohen et al., 2014; Barr and Prillwitz, 2014). As the relevance of mobility research has grown, the disciplinary lines have become increasingly blurred and the use of the term "mobility turn" indicates a transdisciplinary increase in importance for the subject (Rolshoven, 2014). E-mobility forms part of such a mobility turn, i.e. in a form of mobility that is completely fossil fuel-free.

Specific literature focussing on e-mobility in tourism is scarce. Hoppe and Thimm (2018) give an overview of the current literature and elaborate important key aspects such as "cruising range anxiety", i.e. the fear of running out of power during a trip (Gössling, 
2017) and the price (Dosch, 2012) of implementing e-mobility in tourism. According to Jin and Peter (2017), tourism can be used to promote e-mobility, as first-time e-car drivers on holiday may decide to purchase an e-car for private use afterwards. The authors also mention a project in Oregon that integrates e-mobility in tourism by installing charging infrastructure and electric vehicle rentals close to tourism attractions. Other examples similar to the above mentioned can be found in Hawaii (Shaheen and Cohen, 2013), Orlando, FL (Electric Coalition, 2013), Paris (Lesteven and Leurent, 2016) and Kitakyushu in Japan (Nakamura and Naoya, 2016). All of these pursue the idea of offering electric vehicles (especially e-cars and e-bikes) during holidays to promote them for private use. The option of sharing e-vehicles instead of owning them is even more promising in terms of sustainability since, according to Firnkorn and Müller (2015), electric vehicles-sharers are more inclined to do without a car at all than those who share cars with combustion engines.

In rural areas, drivers often automatically become car-dependent and cannot even imagine using alternative transport options at all (Dickinson et al., 2009; Zhang et al., 2018). According to Ebert (2016), e-mobility in a rural tourism context should therefore form part of a multi-modal traffic concept, as e-mobility forms only a part of the solution regarding $\mathrm{CO}_{2}$ emissions.

The Hoppe and Thimm (2018) study that examines the current state of e-mobility in tourism around Lake Constance shows a high fragmentation on the supply side and the current state of information, accessibility and conditions of use that make e-mobility in tourism difficult to achieve.

\subsection{Scenario analysis in tourism}

Scenario analysis, the plausible and practice-based provision of possible representations of the future, is far more common outside the tourism industry than within: the predominant sectors using scenario analysis are international organisations such as the organisation for economic co-operation and development (OECD) or intergovernmental panel on climate change (IPCC), companies in the resource management or finance industries and militaries or planning institutions (Moriarty, 2012). A huge variety of approaches, many of them judgemental, have developed over time (van Doorn, 1982; Bishop et al., 2007; Kosow and Gaßner, 2008; Bradfield et al., 2005). Mietzner and Reger (2005) give an overview of concepts and their respective strengths and weaknesses. Scenarios are never forecasts or predictions - they can only work with current existing knowledge (Postma and Liebl, 2005). Scenario analysis and scenario planning are two technical terms often used interchangeably, but according to Moriarty (2012) "analysis" refers more to the actual construction of sets of possible futures, whereas "planning" refers to practical implications for the industry. Two additional terms, scenario building and scenario development, also appear in the literature, which may be considered steps used to create the scenario before it is analysed (Bishop et al., 2007).

The overall idea behind scenario analysis is to allow planning for the future with only a minimum of surprises and to broaden the span of taking a different future into consideration during decision- making (Mietzner and Reger, 2005). Awedyk and Niezgoda (2018) stress the necessity of scenario planning for any successful form of sustainable tourism or resilience in the tourism industry. For Brand et al. (2013), an interdisciplinary approach is key in scenario analysis. Moriarty (2012), furthermore, formulates the following quality criteria for scenario analysis and planning: cogency, coherency, purpose and pragmatism. Yeoman (2012) adds that effective scenarios must be relevant and plausible. There are scenario analyses for e-mobility in general (Brenna et al., 2016; Auvinen et al., 2016; Thiel et al., 2016), as well as for tourism (Carlisle et al., 2016; Daconto and Sherpa, 2010; Enger et al., 2015; Dubois et al., 2011; Müller and Weber, 2008; Pongthanaisawan et al., 2018), climate change (Intergovernmental Panel on Climate Change (IPCC), 2020) or for the digital 
economy (Pine and Korn, 2011), however, up to now, no scenario analysis for e-mobility in tourism has been carried out. This paper aims to fill this research gap.

The following research questions can be derived from the literature review and this paper is thus addressing them:

$R Q 1$. What do tourists think about Lake Constance region as an e-destination?

$R Q 2$. What could the future of tourism mobility in the Lake Constance region (with special consideration given to e-mobility) look like in 20 years?

RQ3. What are possible tourism mobility scenarios (with special consideration given to emobility) for the Lake Constance region?

$R Q 4$. Is a tourism mobility turn (a transition towards an optimistic scenario) possible in the Lake Constance region?

\section{Methodology}

\subsection{Study area}

The German tourism destination, Lake Constance region (in German: Bodensee), is branded as the "Four-Country Region Bodensee" (Vierländerregion Bodensee) because of the four countries that share borders on the lake, Germany, Switzerland, Austria and Liechtenstein (www.vierlaenderregion-bodensee.info/de/service/about.html). The largest concentration of tourists is on the German side, where the small cities Constance, Überlingen, Friedrichshafen and Lindau attract large numbers of visitors. Therefore, the destination of the Lake Constance region can be termed multipolar because of its lack of a single urban centre (Thimm, 2011). Due to its size and the cross-border situation, Lake Constance region is a very complex destination and thus difficult to manage (Thimm, 2012).

It is a predominantly rural destination dominated by cars, which are used by tourists to travel to, from and around the destination. This is on the one hand due to a lack of rapid public transport options (Hoppe, 2012; Conrady, 2012) and on the other hand due to behavioural habits such as using the car due to familiarity or simply following the tourist "ant trail" (Thimm and Seepold, 2016).

E-mobility in the Lake Constance region is still a niche area, as renting or sharing options and charging stations for e-cars or e-bikes are still quite limited. "Emma" (E-mobil mit Anschluss) in Friedrichshafen is a relevant e-mobility-project in the rural Lake Constance region. The websites www.emobil-im-sueden.de/ and www.seewelle.de/ list mobility offers and services in the Lake Constance region.

As Germany has the longest shoreline at the Lake, most of the survey points were located there: Konstanz, Meersburg and Überlingen. These survey points were chosen because they belong to the tourism hotspots at the Lake. In Switzerland, the city of Kreuzlingen, close to Konstanz, was included in the survey because it is heavily affected by tourism mobility into Konstanz.

\subsection{Method-mix}

A mixed-method approach was applied consisting of an intercept survey, in-depth interviews and a scenario analysis with underlying factor analysis.

The primary data were collected during the months April to June 2016 by student groups identifying the current state, the vision and the expected future (in 20 years) of tourism e-mobility in the Lake Constance region. In total, 781 responses were compiled amongst tourists via a questionnaire, from Germany to Switzerland. The questionnaire was tested in advance by the students and apart from general questions e.g. on age and gender the questions and their respective results are 
illustrated in the results chapter. According to the respective variable, numbers of valid responses were sometimes a bit lower than 781. The sampling method can be described as a convenience sample as the students did not approach the interviewees in a strictly random manner. Because of the high sample size, the clear tendency of the collected survey's results are of importance. The data were then analysed in terms of gaps between vision - expected future and vision - present state. In addition, 13 qualitative structured in-depth interviews were conducted in October/ November 2017 with experts from non governmental organisations (NGOs), tourism businesses and administration and transport providers from the Swiss and German part of the Lake Constance region. The selection criteria were their expertise either on tourism or mobility. The interviews were recorded and transcribed. In case of questions regarding the term "e-mobility", it was explained according to the definition in this paper. Furthermore, a scenario of e-mobility for tourists in the cross-border destination Lake Constance region containing an optimistic (mobility turn), a pessimistic and a realistic scenario was developed based on the existing literature for this topic and Political, Economic, Social, Technical, Legal, Environmental (PESTLE)based factor analysis. Thus, the underlying methodology to answer the research questions was a scenario analysis in combination with descriptive statistical analysis of the collected data and the evaluation of the qualitative in-depth interviews.

The scenario analysis examines key factors (drivers) from ecological, political, technicaleconomic, social and legal fields both from a macro level, such as decarbonisation, climate change or divestment and a micro-level such as e.g. fiscal promotion of e-cars, legislation on e-cars, e-car price or the price of petrol. Thus, it loosely follows the idea of PESTLEanalysis (Cadle et al., 2010). These key factors are then analysed to create different future scenarios.

\section{Results}

The ideal form of mobility in the Lake Constance region for the majority of the interviewees that participated in the intercept survey was not necessarily exclusively e-mobility. It also contained high connectivity and was well planned, included the availability of one's own car, generally amended, i.e. expanded and improved, and based on renewable energies (Figure 1).

Almost $70 \%$ of survey participants view the current state of mobility at Lake Constance as "not so far from that ideal" (Figure 2).

Regarding the future form of mobility in the Lake Constance region in 20 years, the majority of interviewees assumed that there would only be e-mobility, that mobility would be well-planned and coordinated, use of individual cars would still be dominant and mobility would be based on renewable energies, amended and better planned. In summary, the tourists were very optimistic and expected more or less an e-destination in the future, although this does not necessarily represent their ideal form of mobility.

These findings from the intercept surveys were supported by the in-depth interviews which focussed in a more general way on possible futures of tourism mobility around Lake Constance. Most of them mentioned e-mobility and the necessity of better coordination, planning and amendment as possible futures for Lake Constance as a cross-border destination. They also stressed that real e-destination would offer new and interesting marketing options.

In addition to the tourists' assessment, the scenario analysis is used to discuss different future mobility scenarios for the Lake Constance region. Firstly, the relevant factors were identified based on a PESTLE-analysis and rated by the author based on secondary analysis (Table 1). 


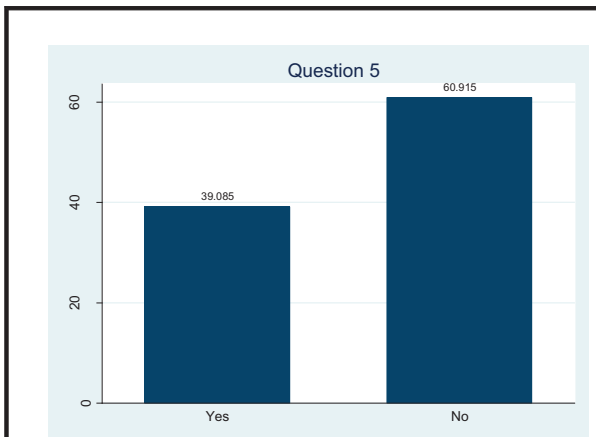

(a)

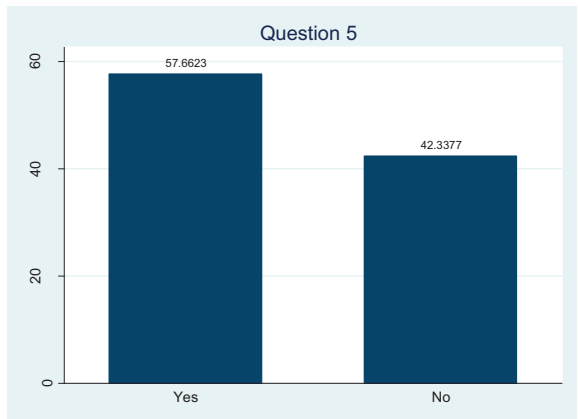

(c)



(b)

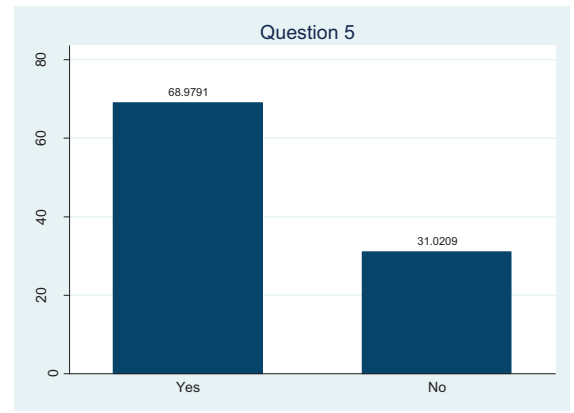

(d)



(e)

Notes: (5a) Exclusively e-mobility $(\mathrm{n}=765), 5 \mathrm{~b})$ mobility is well-planned and coordinated so I can come here anytime from anywhere $(n=765), 5 \mathrm{c})$ it is important to me that I am able to drive my own car to the Lake Constance area anytime from anywhere $(\mathrm{n}=770), 5 \mathrm{~d})$ mobility should be generated by renewable energy $(n=764)$ and 5 e) to avoid traffic jams, tourism mobility should be amended and better planned $(n=771)$. Source: author's illustration 2016, Graph: Leonie Hehn

Some factors fit in more than one field, e.g. divestment, referring to cancelling investments in fossil fuels, belongs to the economic, social and ecological sectors.

According to their influence on other factors, the interdependencies of the factors were analysed. A scale of 0-3 was used, with 0 meaning no influence and 3 a high influencing effect on the other factor:

The higher the active sum, the more influential the factor is; the higher the passive sum, the more the factor is influenced by something else. Legislation and a possible renouncement of climate 


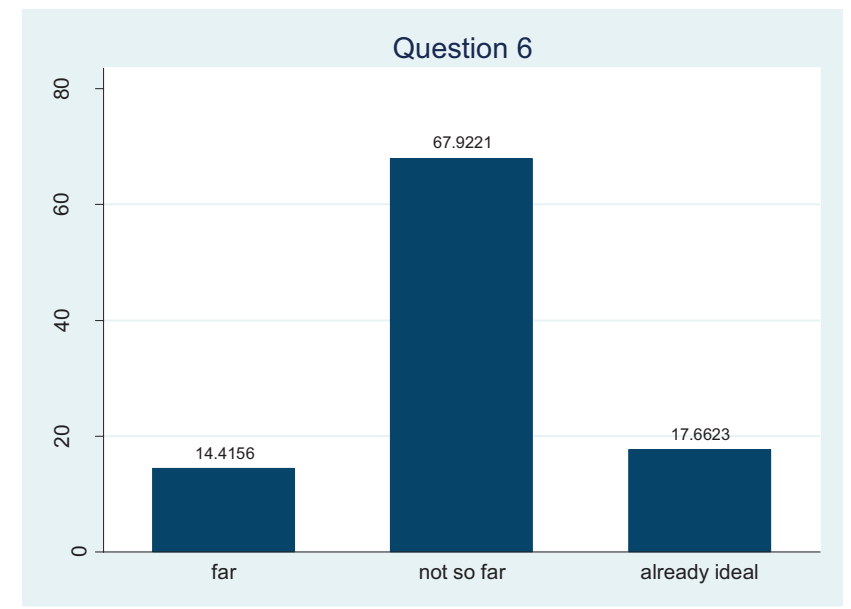

Source: Author's illustration 2016, Graph: Leonie Hehn

change are the most influential factors. Decarbonisation and e-mobility innovations are the most influenced factors.

A scenario analysis based on the importance of the factors of Table 2 then delivers the following future scenarios (Figure 3).

The underlying key factors for the respective tourism mobility scenarios are as follows:

- Scenario I trend extrapolation: tourism-dependent traffic increases, but engines stay the same, factors neutralize or are not strong.

- Scenario II e-destination: e-mobility is the predominant form of tourism mobility, dominant factors: legislation, divestment, e-mobility innovations, decarbonisation, ecar price.

- Scenario III rollback: tourism mobility reverts back to the combustion engine, dominant factors: gasoline price, renouncing climate change, legislation, e-car price.

- Scenario $\mathrm{IVCO}_{2}$ neutrality: tourism mobility reverts back to combustion engine, but $\mathrm{CO}_{2}$ is fully compensated for, dominant factors: gasoline price, legislation, $\mathrm{CO}_{2}$ harvesting/conversion.

\section{Table 1 Factor classification for factor analysis}

\begin{tabular}{|c|c|c|c|c|c|}
\hline Political & Economic & Social & Technological & Legal & Ecological \\
\hline $\begin{array}{l}\text { Renouncing climate } \\
\text { change }\end{array}$ & Divestment & Divestment & $\begin{array}{l}\text { e-mobility innovations (e.g. } \\
\text { range) }\end{array}$ & Legislation & Divestment \\
\hline Decarboni-sation & $\begin{array}{l}\text { Gasoline price } \\
\text { e-car price }\end{array}$ & & $\begin{array}{l}\text { Innovations as alternatives } \\
\text { to e-mobility (e.g. fuel cell) } \\
\mathrm{CO}_{2} \text { harvesting/conversion }\end{array}$ & & Decarbonisation \\
\hline
\end{tabular}


Table 2 Factor analysis (influence of factors on each other)

\begin{tabular}{|c|c|c|c|c|c|c|c|c|c|c|}
\hline Effect on by & $\begin{array}{l}\text { Legis- } \\
\text { lation }\end{array}$ & $\begin{array}{l}\text { Renounce- } \\
\text { ment cc }\end{array}$ & $\begin{array}{l}\text { e-car } \\
\text { price }\end{array}$ & $\begin{array}{l}\mathrm{CO}_{2} \text { con- } \\
\text { version }\end{array}$ & $\begin{array}{c}\text { Gasoline } \\
\text { price }\end{array}$ & $\begin{array}{l}\text { Decarbo- } \\
\text { nisation }\end{array}$ & $\begin{array}{l}\text { Alterna- } \\
\text { tives }\end{array}$ & $\begin{array}{l}\text { e-mobility } \\
\text { innovations }\end{array}$ & divestment & $\begin{array}{l}\text { Active } \\
\text { sum }\end{array}$ \\
\hline Legislation & & 3 & 2 & 2 & 2 & 3 & 2 & 2 & 3 & 17 \\
\hline Renouncing climate & & & & & & & & & & \\
\hline change & 3 & & 2 & 3 & 1 & 3 & 2 & 2 & 2 & 16 \\
\hline e-car price & 2 & 0 & & 1 & 1 & 2 & 3 & 3 & 1 & 13 \\
\hline $\mathrm{CO}_{2}$ conversion & 1 & 0 & 1 & & 2 & 3 & 2 & 2 & 1 & 11 \\
\hline Gasoline price & 1 & 0 & 0 & 2 & & 2 & 1 & 2 & 1 & 9 \\
\hline Decarbonisation & 1 & 0 & 1 & 3 & 2 & & 2 & 2 & 3 & 13 \\
\hline $\begin{array}{l}\text { Alternatives } \\
\text { e-mobility }\end{array}$ & 1 & 0 & 2 & 1 & 2 & 2 & & 3 & 1 & 10 \\
\hline innovations & 1 & 0 & 3 & 0 & 2 & 2 & 1 & & 2 & 8 \\
\hline Divestment & 2 & 1 & 1 & 0 & 2 & 3 & 3 & 3 & & 14 \\
\hline Passive sum & 10 & 4 & 11 & 11 & 11 & 18 & 13 & 16 & 13 & \\
\hline
\end{tabular}

\section{Figure 3 Scenario analysis: pessimistic, optimistic scenario and trend extrapolation}

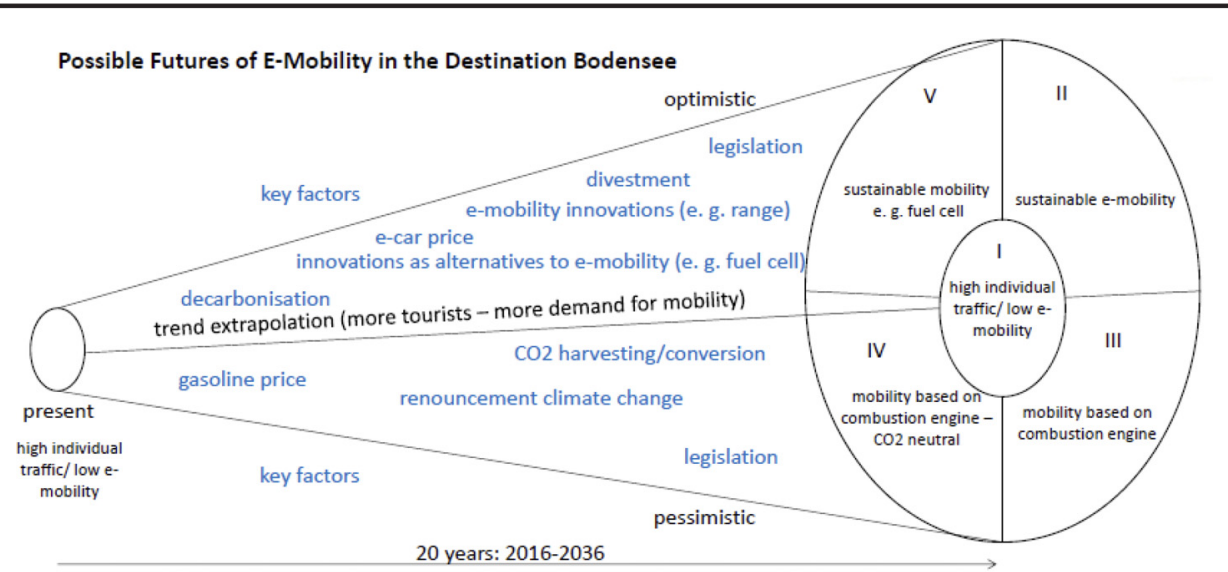

Source: Author's illustration 2017

- Scenario $V$ new sustainable mobility: another innovative engine-based e.g. on fuel cell or $\mathrm{CO}_{2}$ conversion becomes accepted, dominant factors: legislation, innovations as alternatives to e-mobility (e.g. fuel cell or $\mathrm{CO}_{2}$ conversion), divestment, decarbonisation, e-car price.

Scenario II would be an actual e-destination, a result that is also possible according to the data of the intercept survey and the in-depth interviews. The scenarios $\mathrm{V}$ and II are the optimistic scenarios regarding e-mobility, as both combine technological progress and sustainable destination development. Scenarios IV and III are rather pessimistic in this regard and, additionally, from the current perspective rather unlikely, as e-mobility already started to transform the mobility sector. A Scenario I just extrapolates the present into the future and states an unchanged situation, which also is more unlikely.

\section{Discussion}

The results show that tourists are predominantly interested in a mobility that is well-planned and coordinated, does not have traffic jams, and allows them to be independent and to use 
their own car. E-mobility as such is secondary for them although they are in favour of mobility that is based on renewable energies. This contradiction may either be an attitudebehaviour gap - being in favour of green energies, but not wanting to use them for their actual mobility - or due to a lack of knowledge of what mobility based on renewable energies looks like. However, they expect to have an e-destination in the future which is in line with the results of the in-depth interviews with stakeholders from tourism business and administration and complies with Scenario II.

The interviewees' responses furthermore show that the understanding of e-mobility is very often limited to e-cars and e-bikes, leaving out e-trains, e-ships and e-busses as well as eplanes. Trains generally run on electricity anyway, e-busses are gaining ground, especially in cities, and the conversion of all domestic flights to e-flights and the implementation of eships is forcefully being pursued e.g. by the Norwegian Government (The Guardian, 2018; Hockenos, 2018). Still, the idea of e-mobility for many people is often a reduced one, reduced to e-cars and not necessarily linked to the idea of a zero carbon destination.

Regarding practical implications, tourists consider Lake Constance region as an edestination (Scenario II) very possible in the future but they are also quite content with the current state of the mobility situation. The stakeholders in the Lake Constance region from business and government also consider e-destination as a possible future scenario and especially see the marketing options related to that. Applying a scenario analysis, Lake Constance region as an e-destination is just one of five possible futures. Regarding climate change, Scenarios II and IV are the most desirable. As the tourists' attitudes towards these scenarios are positive, it should be possible to make a transition towards them. Therefore, a mobility turn towards one of the optimistic scenarios is in essence possible. The problem - as is often the case in this regard - is on the implementation side. It needs a strong governmental lead in transition management and funding to put insights of the necessity of an e-destination in the face of climate change into practice, as stakeholders may be stuck in choice overload and thus remain inactive (Gössling et al., 2012). This is a necessary requirement to attain Scenario II, an e-destination.

This paper has some limitations, too, as the intercept surveys were not strictly randomised. The in-depth interviews were also based on a convenience sample. However, these disadvantages are compensated to a certain degree via triangulation, i.e. the use of three different approaches to address the research questions.

\section{Conclusion}

In terms of the first research question, tourists think that e-destination is the future of tourist mobility, although they do not consider this the ideal form of mobility. Scenario analysis with an underlying factor analysis based on PESTLE - in the form of Scenario II, the interviews with tourists and stakeholders all lead to the same result regarding the near future of tourism mobility in the Lake Constance region and thus deliver a clear answer to research question number two: it will become an e-destination. Thus, all other scenarios presented in this study are hypothetically possible, but rather unlikely: although several scenarios, including trend extrapolation (Scenario I), rollback (Scenario III), $\mathrm{CO}_{2}$ neutrality (Scenario IV) or new sustainable mobility (Scenario V) are thinkable (RQ3), the interviewed target groups all opted for Scenario II. The RQ4, addressing the likelihood of a transition towards an optimistic scenario, a real mobility turn, requires a decisive and strong governmental transition management, assuring the implementation and involving tourists and stakeholders in that process alike.

The pressure for this real mobility turn is currently becoming more and more intense, as the negative effects of climate change are noticeable and the governments in Europe understood, that the longer they wait (EC, 2020), the more costlier it becomes to pay for the 
damages caused by climate change effects (Intergovernmental Panel on Climate Change (IPCC), 2020). Thus, further research should include specific transition management options for regions or/and scenarios for other, alternative, thinkable future projections that are not covered in this paper.

\section{List of interviews}

20-NOV-2017, interviewee 1, NGO

20-NOV-2017, interviewee 2, tourism business

23-NOV-2017, interviewee 3, administration (business development)

20-NOV- 2017, interviewee 4, administration (transportation)

27-OCT-2017, interviewee 5, administration (transportation)

14-NOV-2017, interviewee 6, administration (transportation)

15-NOV-2017, interviewee 7, administration (transportation)

22-NOV-2017, interviewee 8, administration (economic development)

28-NOV-2017, interviewee 9, transport provider

10-NOV-2017, interviewee 10, transport provider

22-NOV-2017, interviewee 11, transport provider

23-NOV-2017, interviewee 12, transport provider

30-NOV-2017, interviewee 13, transport provider

\section{References}

Auvinen, H., Järvi, T., Kloetzke, M., Kugler, U., Bühne, J.-A., Heinl, F., Kurte, J. and Esser, K. (2016), "Electromobility scenarios: research findings to inform policy", Transportation Research Procedia, Vol. 14, pp. 2564-2573.

Awedyk, M. and Niezgoda, A. (2018), "Resilience planning as an opportunity for future sustainable development in tourism", Operations Research and Decisions, Vol. 2, pp. 23-40.

Barr, S. and Prillwitz, J. (2014), "A smarter choice? Exploring the behaviour change agenda for environmentally sustainable mobility", Environment and Planning: government and Policy, Vol. 32 No. 1, pp. 1-19.

Becken, S. (2004), "How tourists and tourism experts perceive climate change and carbon-offsetting schemes", Journal of Sustainable Tourism, Vol. 12 No. 4, pp. 332-345.

Bishop, P., Hines, A. and Collins, T. (2007), "The current state of scenario development: an overview of techniques", Foresight, Vol. 9 No. 1, pp. 5-25.

Böhler, S., Grischkat, S., Haustein, S. and Hunecke, M. (2006), "Encouraging environmentally sustainable holiday travel", Transportation Research Part A: Policy and Practice, Vol. 40 No. 8, pp. 652-670.

Bradfield, R., Wright, G., Burt, G., Cairns, G. and Van Der Heijden, K. (2005), "The origins and evolution of scenario techniques in long range business planning", Futures, Vol. 37 No. 8, pp. 795-812.

Brand, F.S., Seidl, R., Le, Q.B., Brändle, J.M. and Scholz, R.W. (2013), "Constructing consistent multiscale scenarios by transdisciplinary processes: the case of Mountain regions facing global change", Ecology and Society, Vol. 18 No. 2, p. 43.

Brenna, M., Foiadelli, F., Longo, M. and Zaninelli, D. (2016), "E-Mobility forecast for the transnational ecorridor planning", IEEE Transactions on Intelligent Transportation Systems, Vol. 17 No. 3, pp. 680-689.

Bundesregierung (2011), "Nationaler entwicklungsplan elektromobilität der bundesregierung", Abgerufen am 27.07.2016 unter, available at: www.bmbf.de/files/nationaler_entwicklungsplan_elektromobilitaet.pdf

Cadle, J., Paul, D. and Turner, P. (2010), Business Analysis Techniques, BCS. 
Carlisle, S., Johansen, A. and Kunc, M. (2016), "Strategic foresight for (coastal) urban tourism market complexity: the case of Bournemouth", Tourism Management, Vol. 56, pp. 81-95.

Cohen, S.A., Higham, J.E., Stefan, G. and Peeters, P. (2014), "Understanding and governing sustainable tourism mobility: psychological and behavioural approaches", Routledge, Vol. 43.

Conrady, R. (2012), "Status quo and future prospects of sustainable mobility", in Trends and Issues in Global Tourism 2012, Conrady, R. and Buck, M.M. (Eds), Springer, Heidelberg, pp. 237-260.

Daconto, G. and Sherpa, L.N. (2010), "Applying scenario planning to park and tourism management in Sagarmatha National park, Khumbu, Nepal”, Mountain Research and Development, Vol. 30 No. 2, pp. 103-112.

Dickinson, J.E., Lumsdon, L. and Robbins, D. (2011), "Slow travel: issues for tourism and climate change", Journal of Sustainable Tourism, Vol. 19 No. 3, pp. 281-300.

Dickinson, J.E., Robins, D. and Fletcher, J. (2009), "Representation of transport. A rural destination analysis", Annals of Tourism Research, Vol. 36 No. 1, pp. 103-123.

Döring, T. and Aiken, B. (2011), "E-mobility: realistic vision or hype - an economic analysis", Electrical Review, Vol. 87 No. 3.

Dosch, B. (2012), "Eco-mobility: will new choices of electric drive vehicles change the way we travel?", in Trends and Issues in Global Tourism 2012, Conrady, R. and Buck, M.M. (Eds), Springer, Heidelberg, pp. 261-270.

Dubois, G., Peeters, P., Ceron, J.P. and Gössling, S. (2011), "The future tourism mobility of the world population: emissiongrowth versus climate policy", Transportation Research Part A: Policy and Practice, Vol. 45 No. 10 , pp. 1031-1042.

Ebert, C. (2016), "Erfahrungsbericht und Überblick zum Projekt e-GAP: Modellkommune Elektromobilität Garmisch-Partenkirchen. Elektromobilität im ländlich-touristischen Raum als Baustein für eine nachhaltige Entwicklung", edited by Christian Jacoby und Sandra Wappelhorst, Verlag der ARLAkademie für Raumforschung und Landesplanung, Hannover, pp. 107-125.

Electric Coalition (2013), "Drive electric Orlando, a first-of-its-kind electric car rental initiative", launched on September 5th, 2013, available at: www.electrificationcoalition.org/DEOLaunch (Accessed 15 July 2019).

Enger, A., Sandvik, K. and Iversen, K.E. (2015), "Developing scenarios for the Norwegian travel industry 2025", Journal of Tourism Futures, Vol. 1 No. 1, pp. 6-18.

European Commission (2020), "A European green deal”, available at: https://ec.europa.eu/info/strategy/ priorities-2019-2024/european-green-deal_en (accessed 4 June 2020).

Firnkorn, J. and Müller, M. (2015), "Free-floating electric car sharing-fleets in smart cities: the dawning of a post-private car era in urban environments?", Environmental Science \& Policy, Vol. 45, pp. 30-40.

Friedl, C., Schmied, M. and Götz, K. (2005), Traumziel Nachhaltigkeit. Innovative Vermarktungskonzepte Nachhaltiger Tourismusangebote Für Den Massenmarkt, INVENT Tourismus. Berlin.

Gartner, G. (2020), “Electro-Mobility (e-mobility)”, available at: www.gartner.com/en/informationtechnology/glossary/electro-mobility-e-mobility (accessed 4 February 2020).

Gössling, S. (2009), "Carbon neutral destinations: a conceptual analysis", Journal of Sustainable Tourism, Vol. 17 No. 1, pp. 17-37.

Gössling, S. (2017), The Psychology of the Car: Automobile Admiration, Attachment, and Addiction, Elsevier, Amsterdam.

Gössling, S., Hall, C.M., Ekström, F., Engeset, A.B. and Aall, C. (2012), "Transition management: a tool for implementing sustainable tourism scenarios?", Journal of Sustainable Tourism, Vol. 20 No. 6, pp. 899-916, doi: 10.1080/09669582.2012.699062.

Götz, K., Loose, W., Schmied, M. and Schubert, S. (2003), "Mobility styles in leisure time", Paper presented at 10th International Conference on Travel Behaviour Research, Moving through nets: The physical and social dimensions of travel, August 10-15. Lucerne.

Guiver, J., Lumsdon, L., Weston, R. and Fergusson, M. (2007), "Do buses help meet tourism objectives? The contribution and potential of scheduled buses in rural destination areas", Transport Policy, Vol. 14 No. 4, pp. 275-282. 
Hockenos, P. (2018), "Norway's newest ships give a glimpse into the future of sustainable seafaring", available at: www.smithsonianmag.com/innovation/norways-newest-ships-give-glimpse-into-future-ofsustainable-seafaring-180970326/ (accessed 20 July 2019).

Hoppe, M. (2012), "Mobility lake. Nachhaltige mobilität für tourismus und freizeit am bodensee", available at: www.zhaw.ch/de/engineering/institute-zentren/ine/nachhaltige-transportsysteme/mobility-lake/ (accessed 19 August 2016).

Hoppe, M. and Thimm, T. (2018), "E-mobility in tourism: why new mobility solutions have to overcome borders", Spaces and Flows: An International Journal of Urban and Extra Urban Studies, Vol. 9 No. 4, pp. 35-44.

Intergovernmental Panel on Climate Change (IPCC) (2020), "Global warming of 1,5 degree Celsius", available at: www.ipcc.ch/sr15/ (accessed 3 June 2020).

Jin, L. and Peter, S. (2017), "Literature review of electric vehicle consumer awareness and outreach activities", Working paper 2017-03, International Council on Clean Transportation, Wilmington.

Kagerbauer, M., Heilig, M., Mallig, N. and Vortisch, P. (2015). "Wirkungen zukünftiger mobilität: mobiTopp-simulationswerkzeug zur integration von carsharing und elektromobilität in die mobilitätslandschaft".

Kosow, H. and Gaßner, R. (2008), "Methoden der zukunfts- und szenarioanalyse", Überblick, Bewertung Und Auswahlkriterien, Institut für Zukunftsstudien und Technologiebewertung, Berlin.

Lesteven, G. and Leurent, F. (2016), "Electromobility for tourists: testing business models in the paris region", Transportation Research Procedia, Vol. 19, pp. 164-175.

Lumsdon, L.M. and McGrath, P. (2011), "Developing a conceptual framework for slow travel: a grounded theory approach", Journal of Sustainable Tourism, Vol. 19 No. 3, pp. 265-279.

Mietzner, D. and Reger, G. (2005), "Advantages and disadvantages of scenario approaches for strategic foresight”, International Journal of Technology Intelligence and Planning, Vol. 1 No. 2, pp. 220-239.

Moriarty, J.P. (2012), "Theorising scenario analysis to improve future perspective planning in tourism", Journal of Sustainable Tourism, Vol. 20 No. 6, pp. 779-800.

Müller, H. and Weber, F. (2008), "Climate change and tourism - scenario analysis for the Bernese Oberland in 2030”, Tourism Review, Vol. 63 No. 3, pp. 57-71.

Nakamura, H. and Naoya, A. (2016), "Tourist decisions in renting various personal travel modes: a case study in Kitakyushu city, Japan”, Tourism Management, Vol. 55, pp. 85-93.

Pine, B.J., II. and Korn, K.C. (2011), "Infinite possibility", Creating Customer Value on the Digital Frontier, Berrett-Koehler Publishers, San Francisco, CA.

Pongthanaisawan, J., Wangjiraniran, W., Chuenwong, K. and Pimonsree, L. (2018), "Scenario planning for low carbon tourism city: a case study of Nan", Energy Procedia, Vol. 152, pp. 715-724.

Postma, J.B.M. and Liebl, F. (2005), "How to improve scenario analysis as a strategic management tool?", Technological Forecasting \& Social Change, Vol. 72, pp. 161-173.

Rolshoven, J. (2014), "(invitation to) cultural debate".

Scott, D., Peeters, P. and Gössling, S. (2010), "Can tourism deliver its 'aspirational' greenhouse gas emission reduction targets?", Journal of Sustainable Tourism, Vol. 18 No. 3, pp. 393-408.

Shaheen, S. and Cohen, A. (2013), "Carsharing and personal vehicle services: worldwide market developments and emerging trends", International Journal of Sustainable Transportation, Vol. 7 No. 1, pp. 5-34.

The Guardian (2018), "Norway aims for all short-haul flights to be 100\% electric by 2040", available at: www.theguardian.com/world/2018/jan/18/norway-aims-for-all-short-haul-flights-to-be-100electric-by-2040 (accessed 20 July 2019).

Thiel, C., Nijs, W., Simoes, S., Schmidt, J., van Zyl, A. and Schmid, E. (2016), "The impact of the EU car $\mathrm{CO} 2$ regulation on the energy system and the role of electro-mobility to achieve transport decarbonisation", Energy Policy, Vol. 96, pp. 153-166.

Thimm, T. (2011), "Coopetition als managementgrundlage der internationalen destination bodensee", in Bocksberger, P. and Schuckert, M. (Eds), Innovationen in Tourismus Und Freizeit, Erich Schmidt Verlag, Berlin, pp. 195-212. 
Thimm, T. (2012), "Comparison of management styles of cross-border destinations: Lake Constance, upper rhine and the catlins", in Kagermeier, A. and Saarinen, J. (Eds), Transforming and Managing Destinations. Tourism and Leisure in a Time of Global Change and Risk, MetaGIS, Mannheim, pp. 105-120.

Thimm, T. and Seepold, R. (2016), "Past, present and future of tourist tracking", Journal of Tourism Futures, Vol. 2 No. 1, pp. 43-55.

Van Doorn, J.W.M. (1982), "Can futures research contribute to tourism policy?", Tourism Management, Vol. 3 No. 3, pp. 149-166.

World Tourism Organisation (UNWTO) (2008), Climate Change and Tourism. Responding to Global Challenges, UNWTO, Madrid.

Yeoman, I. (Ed.). (2012), 2050 - Tomorrow's Tourism, Channel View Publications, Bristol.

Zhang, H., Chen, W., Zhang, Y., Buhalis, D. and Lu, L. (2018), "National park visitors' car-use intention: a norm-neutralization model", Tourism Management, Vol. 69, pp. 97-108, doi: 10.1016/j.tourman.2018.06.001.

Zografos, K.G., Androutsopoulos, K.N. and Spitadakis, V. (2009), "Design and assessment of an online passenger information system for integrated multimodal trip planning", IEEE Transactions on Intelligent Transportation Systems, Vol. 10 No. 2, pp. 311-323.

Zschiegner, A.K. and Yan, J. (2006), "A long march ahead? Consumer attitudes and economic preferences for sustainable tourism in the domestic Chinese tourism market", Paper presented at E-CLAT Climate change and tourism conference.

\section{Further reading}

Blotevogel, H.H. Spiekermann, K. and Wegener, M. (2013), "Deutschland in europa. Ergebnisse des programms ESPON 2013. Heft 2: metropolen und ländliche räume. BBSR - bundesinstitut für bau-, stadtund raumforschung im BBR - bundesamt für bauwesen und raumordnung (hrsg.)".

Born, K.M. (2011), "Ländliche räume in deutschland. Differenzierungen, entwicklungspfade und -brüche", Geographische Rundschau, Vol. 63, pp. 4-10. Jg., H. 2.

Chen, Y. (2011), "Nachhaltige mobilität im bodenseetourimus", Direktmarketing des ÖPNV bei Bodenseegästen.

Dickinson, J.E. and Dickinson, J.A. (2006), "Local transport and social representations: challenging the assumptions for sustainable tourism", Journal of Sustainable Tourism, Vol. 14 No. 2, pp. 192-208.

E-Mobil BW GmbH (2016), available at: www.e-mobilbw.de/de/ ( accessed 17 November 2016).

Reddemann, S. (2011), "Erlebnis. Fahrten. Bodensee - Potenzialanalyse für touristische erlebnislinien am bodensee zur attraktivitätssteigerung von nachhaltigen verkehrsmitteln".

Scherer, R. and Strauf, S. (2010), "Positionierung der internationalen tourismusregion Bodensee", available at: www.dasbodenseeprojekt.eu/wp-content/uploads/2010/05/Ergebnisse-Ist-Analyse.pdf (accessed 19 September 2016).

\section{Corresponding author}

Tatjana Thimm can be contacted at: thimm@htwg-konstanz.de

For instructions on how to order reprints of this article, please visit our website: www.emeraldgrouppublishing.com/licensing/reprints.htm

Or contact us for further details: permissions@emeraldinsight.com 